Jurnal Pengabdian kepada Masyarakat

(Indonesian Journal of Community Engagement)
Vol.4, No.2, Maret 2019, Hal $129-140$

DOI:http://doi.org/ 10.22146/jpkm.33581

Tersedia onlinedi http://jurnal.ugm.ac.id/jpkm

\title{
Transfer Teknologi Produksi Natural Soap-Base untuk Kreasi Sabun Suvenir
}

\author{
*Ari Asnani, Eva Vaulina Yulistia Delsy, Hartiwi Diastuti \\ Jurusan Kimia, Fakultas MIPA, Universitas Jenderal Soedirman, \\ Jl. Dr. Soeparno, Karangwangkal, Purwokerto 53123, Jawa Tengah \\ *ari.asnani@unsoed.ac.id
}

Submisi: 28 Februari 2018; Penerimaan: 22 Januari 2019

Kata Kunci: coldprocess, hotprocess, sabun suvenir

\section{Keywords: cold-process, hot-process, souvenir soap}

ABSTRAK Kegiatan Pengabdian kepada Masyarakat Program Penerapan IPTEKS (Ilmu Pengetahuan, Teknologi, dan Sains) telah dilaksanakan di Unit Kewirausahaan dan Prakarya, Madrasah Aliyah Negeri (MAN) Purbalingga. Tujuan kegiatan ini adalah (1) transfer teknologi pembuatan soap-base berbasis minyak untuk membuat sabun dasar alami (natural soap-base); (2) transfer teknologi metode cold-process dan hot-process untuk kreasi sabun suvenir varian bentuk dan warna; serta (3) transfer pengetahuan tentang ragam kemasan produk sabun suvenir. Metode yang diterapkan meliputi pendidikan siswa, pelatihan, serta difusi iptek untuk memproduksi sabun suvenir. Hasil post-test menunjukkan bahwa terjadi peningkatan pengetahuan mitra tentang reaksi penyabunan ( $0 \%$ menjadi $50 \%)$, prinsip pembuatan sabun ( $0 \%$ menjadi $54,2 \%)$, serta pengetahuan tentang bahan baku, bahan tambahan, dan peralatan untuk membuat sabun. Tiga faktor utama yang dapat mendorong anggota mitra agar mau membuat sabun adalah rasa ingin tahu tentang proses pembuatan sabun secara lebih dalam (70,8\%); peluang usaha (62,5\%), dan keinginan untuk membuat sabun sesuai dengan yang diinginkan/kreasi sabun $(29,1 \%)$. Kegiatan pengabdian kepada masyarakat ini diharapkan dapat bermanfaat bagi mitra, yakni memberi keterampilan untuk memproduksi sabun suvenir berbahan baku alami dengan beragam bentuk dan warna.

ABSTRACT IPTEKS-based community service has been done with the Entrepreneurship and Workshop unit of MAN Purbalingga. The objectives of the activities were (1) Transferring of soap making technology to produce natural soap-base; (2) Transferring of cold-process and hot-process methods for the creation of soap-souvenirs with various shapes and colors; and (3) Transferring the packaging knowledge for souvenir soap products. The methods applied include student education, training, and the diffusion of science and technology to produce souvenir soap. The post-test results showed that there was an increased knowledge of the partners on saponification reactions (0\% to 50\%), soap making principles (0\% to 54.2\%), as well as the understanding of raw materials, additives, and soap-making equipment. The three main factors that could encourage the partners to make soap were an eagerness on how to make soap (70.8\%); business opportunity (62.5\%), and wanted to make soap creations $(29.1 \%)$. This community service activity was expected to provide benefits in the form of partnership ability to produce souvenir soap made from natural ingredients with various shapes and colors. 


\section{PENDAHULUAN}

Sabun adalah agen pembersih yang dibuat melalui reaksi saponifikasi antara basa natrium atau kalium dengan asam lemak dari minyak nabati atau lemak hewani (IndonesiaSNI, 1994). Bahan penyusun sabun terdiri atas bahan utama dan bahan pendukung. Bahan utama berupa berbagai jenis minyak nabati (berbentuk cair) atau lemak hewan (berbentuk padat). Bahan pendukung yang umum dipakai dalam proses pembuatan sabun, antara lain, pewangi, pewarna, natrium klorida, natrium karbonat, dan natrium fosfat. Bahan-bahan pendukung yang ditambahkan ke dalam sabun juga berfungsi untuk mempertinggi kualitas produk sabun sehingga menarik konsumen.

Metode pembuatan sabun terdiri atas metode cold process dan hot process (Mabrouk, 2005). Perbedaan mendasar dari dua metode tersebut terletak pada suhu yang digunakan ketika proses pembuatan sabun. Pembuatan sabun dasar alami (natural soap-base) hanya menggunakan minyak dan basa alkali serta meminimalisasi penggunaan bahan-bahan kimia. Selanjutnya, produk natural soap-base yang diperoleh dapat dimodifikasi dengan metode melt and pour (leleh dan tuang) untuk menghasilkan aneka ragam sabun suvenir.

Sabun suvenir dikategorikan sebagai hasil kerajinan fungsional karena tidak hanya berfungsi sebagai dekorasi, tetapi juga sebagai barang kebutuhan sehari-hari. Pembuatan sabun suvenir akan menjadi peluang wirausaha yang prospektif karena kebutuhan akan sabun selalu ada dan terus meningkat. Berdasarkan hal tersebut, kegiatan pengabdian kepada masyarakat program penerapan Ipteks di Madrasah Aliyah Negeri (MAN) Purbalingga dengan judul "Transfer Teknologi Produksi Natural Soap-Base untuk Kreasi Sabun Suvenir" ini dilakukan.

Pemilihan MAN Purbalingga sebagai mitra kegiatan pengabdian masyarakat didasarkan pada ciri khas yang dimiliki, yakni keberadaan Unit Kewirausahaan dan Prakarya (KDP) sebagai salah satu kegiatan wajib bagi semua siswa kelas kelas X, XI, dan XII pada semester genap. Tujuan kegiatan unit KDP adalah melatih dan memberikan keterampilan pada siswa MAN Purbalingga agar dapat mandiri dan mampu berwirausaha.

Secara spesifik, kegiatan unit KDP untuk siswa kelas $\mathrm{X}$ bertujuan untuk meningkatkan kreativitas siswa melalui pembuatan aneka kerajinan berbasis limbah; untuk siswa kelas XI bertujuan untuk meningkatkan kemampuan pemasaran produk yang mencakup pengemasan dan marketing; dan untuk siswa kelas XII berfokus pada sistem manajerial desain produksi.

Potensi yang dimiliki MAN Purbalingga dengan adanya unit KDP adalah kreativitas siswa dengan hasil kerajinan yang inovatif. Hingga saat ini, kegiatan yang telah dilaksanakan oleh unit KDP meliputi pembuatan kerajinan dari bahan limbah plastik dan botol plastik, kerajinan dari bahan lunak dan keras, serta kerajinan dari limbah tekstil. Produk-produk hasil kegiatan unit KDP adalah berbagai produk kerajinan tangan, namun produk yang dihasilkan dari penerapan teori saponifikasi untuk pembuatan sabun belum pernah dilakukan. Berdasarkan hal tersebut, tujuan kegiatan ini adalah (a) transfer pengetahuan pembuatan soap-base berbasis minyak untuk pembuatan sabun dasar alami (natural soap-base); (b) transfer teknologi metode cold-process dan hot-process untuk kreasi sabun suvenir varian bentuk dan warna; serta (c) transfer pengetahuan mengenai ragam kemasan produk sabun suvenir. 


\section{MASALAH}

Pada reaksi saponifikasi, basa $\mathrm{NaOH} / \mathrm{KOH}$ akan meng-hirolisis minyak/lemak menjadi asam lemak dan gliserol. Asam lemak kemudian berikatan dengan natrium/kalium membentuk sabun. Sabun yang dibuat dari $\mathrm{NaOH}$ dikenal dengan sebutan sabun keras (hard soap), sedangkan sabun yang dibuat dari $\mathrm{KOH}$ dikenal dengan sebutan sabun lunak (soft soap).

Teori penyabunan atau proses saponifikasi umumnya dipelajari oleh siswa dalam mata pelajaran IPA, namun teori ini belum pernah dipraktikkan untuk menghasilkan produk sabun. Kendala utama penerapan teori penyabunan atau proses saponifikasi adalah kurangnya informasi mengenai prosedur proses ini, bahan utama dan bahan pendukung, serta ketersediaan alat-alat yang diperlukan. Oleh karena itu, pendidikan dan pelatihan produksi natural soap-base perlu dilakukan untuk meningkatkan pengetahuan serta keterampilan siswa.

\section{METODE}

\subsection{Lokasi dan Mitra}

Transfer teknologi produksi sabun diterapkan pada siswa kelas X MAN Purbalingga yang mengikuti kegiatan unit KDP pada semester genap tahun akademik 2016/2017 dengan didampingi guru pembimbing, yakni Mukholiq Adi Susetyo, S.Pd., M.Sc., dan Nur Istimatullah, S.Si.

\subsection{Metode Kegiatan}

Metode yang diterapkan dalam kegiatan ini adalah (a) metode pendidikan untuk meningkatkan pengetahuan; (b) metode pelatihan untuk meningkatkan keterampilan siswa; dan (c) difusi ipteks untuk menghasilkan produk sabun suvenir.

Penyelenggaraan pendidikan bagi siswa dilakukan dalam bentuk ceramah mimbar. Materi diberikan dalam bentuk modul dan disampaikan oleh narasumber, yakni tim pengabdian masyarakat. Adapun pelatihan yang dilaksanakan berkaitan dengan proses pembuatan sabun dengan metode cold-process untuk menghasilkan sabun opaque dan metode hot-process untuk menghasilkan sabun transparan (sabun bening). Dua formula sabun yang dipraktikkan sebagai berikut.

(1) Formula sabun untuk metode dingin: minyak sawit (150 g), minyak kelapa (100 g), minyak jarak (100 g), $\mathrm{NaOH}$ (53 g), dan aquades (127 g).

(2) Formula sabun untuk metode panas: minyak kelapa (60 g), asam stearat (20 g), $\mathrm{NaOH}$ (13 $\mathrm{g}$ ), etanol (20 g), gliserin (6 g), sukrosa (30 g), dan aquades (57 g).

Alat-alat yang digunakan untuk memproduksi sabun meliputi timbangan digital, hand-blender, panci double boiler, slow cooker, hot-plate, variasi cetakan sabun silicone, rak plastik untuk pengeringan sabun, gelas kaca, spatula silicone, pengaduk kayu, saringan stainless steel kecil, dan peralatan penunjang lainnya. 


\subsection{Evaluasi Kegiatan}

Evaluasi kegiatan terdiri atas evaluasi peningkatan pengetahuan dan keterampilan siswa melalui pre-test dan post-test secara tertulis. Pertanyaan yang membutuhkan jawaban ya/tidak berjumlah delapan dan ada satu pertanyaan essay. Essay pada pre-test menanyakan tiga faktor utama yang menentukan agar siswa membeli sabun. Adapun essay pada post-test menanyakan tiga faktor utama yang dapat mendorong siswa agar mau membuat sabun. Pertanyaan tersebut digunakan untuk mengetahui minat siswa mengembangkan sabun suvenir sebagai kegiatan wirausaha.

\section{HASIL DAN PEMBAHASAN}

Pelaksanaan kegiatan diawali dengan penyelenggaraan pre-test pada awal pertemuan untuk mengetahui pemahaman dasar siswa tentang proses pembuatan sabun. Responden berjumlah 22 siswa. Hasil pre-test menunjukkan bahwa hanya 1 (4,5\%) dari 22 siswa yang pernah membuat sabun (Tabel 1). Pada umumnya siswa antusias ingin membuat sabun (100\%), namun siswa belum memahami teori reaksi penyabunan, prinsip pembuatan sabun, prosedur, bahan baku, bahan tambahan, serta peralatan yang harus digunakan untuk membuat sabun.

Tabel 1 Hasil Evaluasi Awal (Pre-test) dari Para Peserta Pelatihan Kreasi Sabun Suvenir $(n=22)$

\begin{tabular}{|c|c|c|c|}
\hline No. & Item Pertanyaan & Ya (\%) & Tidak (\%) \\
\hline 1. & Apakah Anda pernah membuat sabun? & 4,5 & 95,5 \\
\hline 2. & Apakah Anda ingin membuat sabun? & 100 & 0 \\
\hline 3. & Apakah Anda memahami teori reaksi penyabunan? & 0 & 100 \\
\hline 4. & $\begin{array}{l}\text { Apakah Anda mengetahui prinsip pembuatan } \\
\text { sabun? }\end{array}$ & 0 & 100 \\
\hline 5. & $\begin{array}{l}\text { Apakah Anda mengetahui prosedur pembuatan } \\
\text { sabun? }\end{array}$ & 4,5 & 95,5 \\
\hline 6. & $\begin{array}{l}\text { Apakah Anda mengetahui bahan baku yang dapat } \\
\text { digunakan untuk membuat sabun? }\end{array}$ & 27,3 & 72,7 \\
\hline 7. & $\begin{array}{l}\text { Apakah Anda mengetahui bahan-bahan tambahan } \\
\text { yang harus diberikan pada pembuatan sabun? }\end{array}$ & 22,7 & 77,3 \\
\hline 8. & $\begin{array}{l}\text { Apakah Anda mengetahui peralatan yang } \\
\text { diperlukan dalam pembuatan sabun? }\end{array}$ & 13,6 & 86,4 \\
\hline
\end{tabular}

Sumber: Data primer diolah (2017)

Ada dua belas faktor utama yang mendorong siswa untuk membeli sabun (Tabel 2). Tiga faktor utamanya adalah sabun untuk kebersihan diri, pakaian, dan lingkungan $(63,6 \%)$; aroma/harum sabun (50\%); dan harga sabun (41\%).

Kegiatan selanjutnya adalah pemaparan materi tentang produksi sabun suvenir. Kegiatan ini bertujuan untuk meningkatkan pengetahuan serta memperluas wawasan siswa. Kegiatan diselenggarakan di laboratorium IPA MAN Purbalingga. Materi diberikan dalam bentuk modul dan disampaikan dalam tiga kali pertemuan. Setiap pertemuan dipaparkan tiga materi sehingga total materi yang diberikan adalah sembilan. 
Tabel 2 Hasil Survei Mengenai Faktor-Faktor Utama yang Dipertimbangkan Peserta Pelatihan Ketika Membeli Sabun ( $\mathrm{n}=22)$

\begin{tabular}{clc}
\hline No. & Faktor-faktor pembelian sabun & Jumla $(\%)$ \\
\hline 1. & Kebersihan diri, pakaian, dan & 63,6 \\
& lingkungan & \\
2. & Aroma/harum & 50,0 \\
3. & Harga & 40,9 \\
4. & Kesehatan & 36,3 \\
5. & Kualitas & 36,3 \\
6. & Penampilan fisik & 13,6 \\
7. & Kecantikan & 9,0 \\
8. & Manfaat & 9,0 \\
9. & Busanya banyak dan lembut & 4,5 \\
10. & Merek & 4,5 \\
11. & Bahannya & 4,5 \\
12. & Enak dipakai & 4,5 \\
\hline
\end{tabular}

Sumber: Data primer diolah (2017)

Modul yang diberikan terdiri atas dua jenis, yaitu modul pengetahuan dan modul pelatihan. Modul pengetahuan terdiri dari (1) Sejarah dan pemanfaatan sabun; (2) Jenis-jenis minyak nabati untuk pembuatan sabun dan angka penyabunan; (3) Bahan-bahan aditif sabun; (4) Karakteristik sabun; dan (5) Bentuk unik dan menarik dari sabun suvenir.

Sementara, modul pelatihan terdiri atas (1) Produksi natural soap-base dengan metode cold-process; (2) Produksi sabun transparan chip soap dengan metode hot-process; (3) Desain kemasan sabun suvenir; dan (4) Analisis usaha produksi sabun suvenir.

Setelah pemaparan materi, siswa dibagi menjadi lima kelompok. Masing-masing kelompok berlatih membuat sabun variasi warna dan bentuk dengan arahan dari narasumber. Pelatihan pembuatan sabun dilakukan dengan dua cara, yaitu cold-process (metode dingin) dan hot-process (metode panas).

Pelatihan pertama adalah pembuatan sabun dengan metode dingin tanpa pemanasan atau disebut hand-made soap. Formula yang digunakan merupakan hasil perhitungan menggunakan lye-calculator, yaitu alat bantu untuk menghitung jumlah basa $\mathrm{NaOH}$ yang dibutuhkan guna reaksi saponifikasi minyak tertentu (Dunn, 2007).

Proses pembuatan sabun dengan metode dingin sangat sederhana. Semua minyak dicampur dengan larutan basa natrium hidroksida $(\mathrm{NaOH})$ kemudian diaduk menggunakan hand-blender hingga membentuk trace, yaitu adonan yang mengental dan kaku. Dengan cepat adonan sabun diberi zat warna dan pengharum sambil diaduk sampai homogen (Gambar 1). Selanjutnya, adonan sabun dituang dalam cetakan silicone dan didiamkan agar membeku. Pada suhu ruang, sabun akan mengeras dalam waktu tiga jam. 


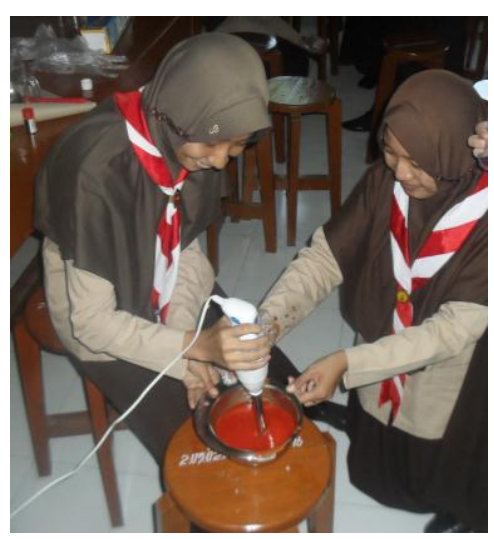

Sumber: Data primer (2017)

Gambar 1. Praktik Pengadukan Bahan Sabun Menggunakan Hand-Blender Pada Metode

Dingin

Pada proses saponifikasi, penggunaan $\mathrm{NaOH}$ secara berlebih akan menyebabkan molekul minyak habis bereaksi sehingga produk sabun yang dihasilkan dapat menyebabkan kulit menjadi gatal dan panas (Dunn, 2010). Berbagai metode dapat dilakukan untuk mencegah timbulnya gatal dan panas akibat $\mathrm{NaOH}$ berlebih antara lain (1) Penggunaan asam klorida encer pada produk sabun untuk menghilangkan kelebihan $\mathrm{NaOH}$ (Mabrouk, 2005); (2) Melakukan pengocokan formula sabun minimal 45 menit untuk menyempurnakan reaksi saponifikasi (Hartini et al., 2017); dan (3) Mengurangi penggunaan jumlah $\mathrm{NaOH}$ agar $\mathrm{NaOH}$ bereaksi tepat dengan minyak yang digunakan (Prabowo et al., 2016).

Pada pelatihan produksi sabun ini, kelebihan $\mathrm{NaOH}$ diminimalkan dengan penghitungan lye calculator untuk mengetahui jumlah $\mathrm{NaOH}$ yang tepat sehingga habis bereaksi dengan minyak kelapa. Proses pematangan atau pemeraman sabun (curing) dilakukan dengan cara mengangin-anginkan produk sabun pada suhu ruang selama minimal dua sampai tiga minggu sebelum digunakan (Gambar 2). Menurut Yuliarti (2018), proses curing pada suhu $37^{\circ} \mathrm{C}$ akan menurunkan kadar air serta menurunkan $\mathrm{pH}$ sabun sehingga kualitas sabun sesuai dengan SNI.

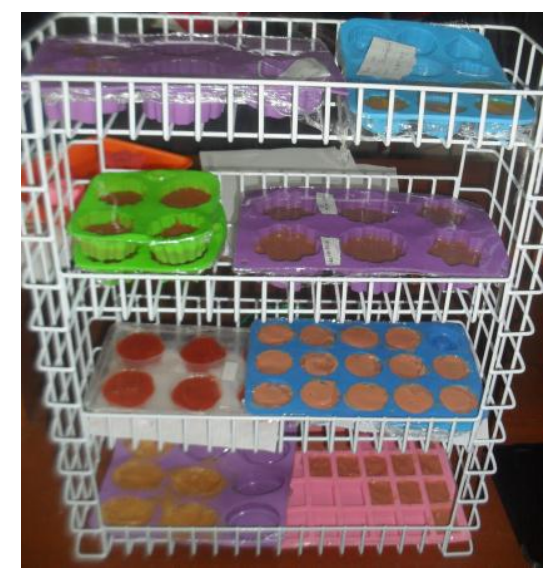

Sumber: Data primer (2017)

Gambar 2. Pencetakan Sabun Menggunakan Cetakan Silicone dan Proses Curing Sabun dengan Cara Diangin-Anginkan 
Sabun yang dihasilkan dengan metode dingin adalah sabun jenis opaque. Contoh produk sabun suvenir jenis opaque hasil pelatihan metode dingin tersaji pada Gambar 3 berikut ini.

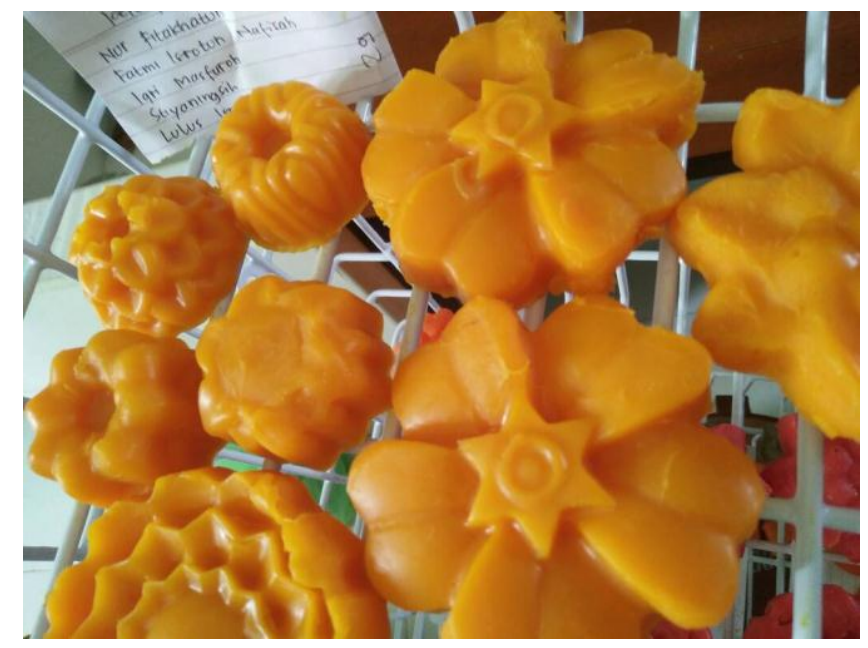

Sumber: Data primer (2017)

Gambar 3. Hasil Produk Sabun Suvenir Jenis Opaque yang Dibuat dengan Metode Dingin

Pelatihan kedua adalah pembuatan sabun dengan metode panas, yakni menggunakan panci double boiler, yaitu dua panci yang satu panci lebih besar daripada panci yang lain. Panci yang lebih besar diisi dengan air dan langsung dipanaskan dengan alat pemanas (pemanas listrik, gas, api). Adapun panci yang lebih kecil digunakan sebagai tempat pembuatan sabun. Panci kecil dimasukkan ke dalam panci besar sehingga panci kecil akan mendapatkan panas dari air yang ada di dalam panci besar (Gambar 4). Alternatif lain selain panci double boiler adalah slow cooker dengan wadah keramik yang tahan terhadap bahanbahan yang digunakan pada proses pembuatan sabun.

Sumber: Data primer (2017)

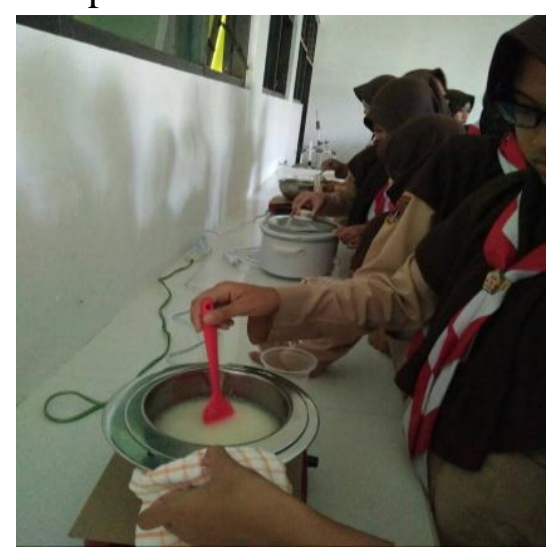

Gambar 4. Proses Pemanasan dengan Panci Double-Boiler atau Slow Cooker pada Metode Panas

Pada prinsipnya semua jenis minyak dapat digunakan sebagai bahan baku pembuatan sabun transparan. Minyak kelapa murni VCO (Sari et al., 2010), minyak sawit (Widyasanti et al., 2017), bahkan minyak jelantah (Priani \& Lukmayani, 2010) telah digunakan sebagai bahan baku pembuatan sabun transparan. Sabun transparan juga dapat dibuat dari campuran 
minyak kelapa dan minyak jarak (Hermani et al., 2010), atau campuran minyak kelapa, minyak sawit, dan minyak zaitun (Agustini \& Winarni, 2017).

Formula sabun transparan dengan metode panas yang digunakan pada kegiatan pengabdian masyarakat ini menggunakan minyak kelapa (Herlina et al., 2017). Proses pembuatan sabun transparan sebagai berikut.

Pertama, minyak kelapa dan asam stearat dipanaskan pada suhu $70^{\circ} \mathrm{C}$ hingga asam stearat larut sempurna. Reaksi saponifikasi dilakukan dengan menambahkan larutan $\mathrm{NaOH}$ ke dalam larutan minyak asam stearat. Proses pengadukan dilakukan hingga reaksi saponifikasi sempurna, yakni dengan terbentuknya trace. Selanjutnya, larutan gula ditambahkan sambil terus dipanaskan hingga menjadi homogeny. Setelah itu, etanol dan gliering dimasukkan sambil diaduk perlahan-lahan hingga menjadi cair dan bening. Larutan gula, etanol, dan gliserin berfungsi untuk melarutkan dan meningkatkan transparansi sabun (Hambali et al., 2005). Selain itu, gliserin merupakan pelembab (humektan) sehingga produk sabun yang dihasilkan akan mampu melembabkan kulit.

Agar sabun suvenir tampak menarik dapat ditambahkan zat warna. Terakhir, campuran sabun dituangkan ke dalam cetakan silicone untuk memudahkan pelepasan setelah sabun menjadi padat. Sabun kemudian disimpan selama semalam dengan ditutup kain tipis. Setelah mengeras, sabun dapat dikeluarkan dari cetakan dan langsung dapat digunakan (Gambar 5).

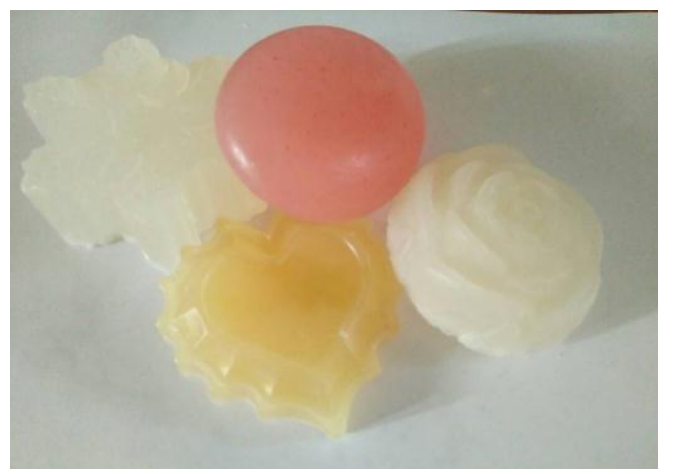

Sumber: Data primer (2017)

Gambar 5. Produk Sabun Transparan yang Dihasilkan dengan Metode Panas

Pada metode panas, produk sabun yang dihasilkan merupakan sabun transparan karena penggunaan gliserin. Sabun dapat langsung digunakan tanpa melalui proses curing karena proses pemanasan mampu menyempurnakan reaksi saponifikasi. Hasil sabun dari metode panas tersaji pada Gambar 6. Karakteristik sabun transparan dibentuk berdasarkan prosedur standar mutu dan cara uji sabun mandi (Departemen Kesehatan R.I., 1996) Karakteristik sabun transparan yang dibentuk menunjukkan bahwa produk sabun tersebut memiliki karakter sabun yang sesuai dengan SNI 06-3532-1994 (Herlina et al., 2017).

Pelatihan ketiga adalah mengemas produk sabun menjadi suvenir. Pelatihan ini penting dilakukan karena kemasan mempunyai fungsi penting, yakni sebagai pelindung produk sekaligus menjadi daya tarik agar masyarakat membeli produk tersebut (Cenadi, 2000). Bahan pengemas yang dipilih adalah plastik bening mika agar variasi bentuk dan warna sabun jelas terlihat oleh konsumen untuk meningkatkan daya tarik produk (Setyawan, 2013). Kemasan digunakan dalam berbagai bentuk dan ukuran karena fungsi produk sebagai 
suvenir. Sabun suvenir yang telah dikemas secara unik diharapkan mampu meningkatkan daya jual produk karena fungsi akhir dari kemasan adalah meningkatkan penjualan (Gambar 6).

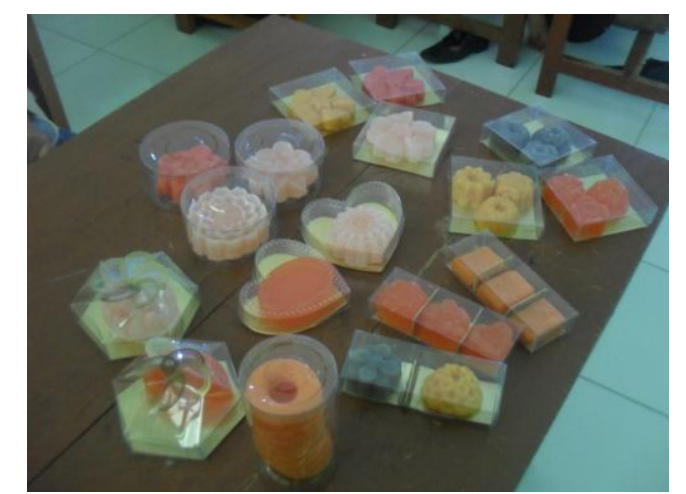

Sumber: Data primer (2017)

Gambar 6. Ragam Sabun Suvenir Variasi Warna dan Bentuk

Pelatihan terakhir adalah analisis usaha untuk memberikan gambaran besarnya biaya investasi, biaya yang harus dikeluarkan, dan besarnya keuntungan yang dapat diperoleh dari suatu usaha produksi. Analisis ekonomi penting dilakukan karena pembuatan sabun suvenir termasuk dalam proses produksi yang berorientasi bisnis. Hal-hal yang dianalisis mencakup perhitungan (1) modal investasi, (2) biaya operasional, (3) harga pokok bahan, (4) harga pokok produksi, (5) keuntungan, dan (6) waktu kembali modal (Permono, 2015).

Tabel 3. Hasil Evaluasi Akhir (Post-Test) dari Peserta Pelatihan Kreasi Sabu Suvenir

\begin{tabular}{clcc}
\hline No. & \multicolumn{1}{c}{ Pertanyaan } & Ya $(\%)$ & Tidak $(\%)$ \\
\hline 1. & Apakah Anda pernah membuat sabun? & 83 & 17 \\
2. Apakah Anda ingin membuat sabun? & 100 & 0 \\
3. Apakah Anda memahami teori reaksi penyabunan? & 50 & 50 \\
4. Apakah Anda mengetahui prinsip pembuatan sabun? & 54,2 & 45,8 \\
5. Apakah Anda mengetahui prosedur pembuatan sabun? & 83 & 17 \\
6. Apakah Anda mengetahui bahan baku yang dapat & 83 & 17 \\
& & \\
7. digunakan? & 83 & 17 \\
& Apakah Anda mengetahui bahan-bahan tambahan yang & & 17 \\
8. Apak diberikan? & 83 & \\
& & \\
\hline
\end{tabular}

Sumber: Data primer diolah (2017)

Pada akhir rangkaian kegiatan dilakukan evaluasi dalam bentuk post-test untuk mengetahui peningkatan pengetahuan siswa. Post-test diikuti oleh responden yang berjumlah 24 siswa (Tabel 3). Hasil post-test menunjukkan adanya peningkatan pemahaman siswa tentang teori reaksi penyabunan dan prinsip pembuatan sabun, yakni dari $0 \%$ menjadi $50 \%$ dan 54,2\%. Pemahaman siswa belum mencapai $100 \%$ karena praktik dilakukan secara berkelompok. Adapun tingkat pengetahuan dan pemahaman siswa tentang bahan baku, bahan tambahan, serta peralatan membuat sabun meningkat hingga $83 \%$. 
Tabel 4. Hasil Survei Faktor-Faktor yang Mendorong agar Siswa Mau Membuat Sabun

\begin{tabular}{clc}
\hline No. & \multicolumn{1}{c}{ Faktor-Faktor } & $\%$ \\
\hline 1. & Ingin tahu cara membuat sabun lebih dalam & 70,8 \\
2. & Peluang usaha & 62,5 \\
3. & Ingin membuat sabun sesuai yang diinginkan/kreasi sabun & 29,1 \\
4. & Ingin membuat sabun berkualitas/banyak busa & 20,8 \\
5. & Berhemat & 20,8 \\
6. & Sabun memiliki banyak manfaat & 16,6 \\
7. & Mengembangkan wawasan & 16,6 \\
8. & Ingin membuat sabun wangi & 16,6 \\
9. & Mengetahui reaksi kimia pembuatan sabun & 16,6 \\
10. & Mengetahui kandungan yang terdapat dalam sabun & 12,5 \\
11. & Ingin membuat sabun yang sehat/antibakteri & 8,3 \\
12. & Menjaga kesehatan & 4,1 \\
13. & Ingin membuat sabun tanpa bahan kimia & 4,1 \\
14. & Bisa memanfaatkan bahan-bahan di sekitar kita & 4,1 \\
\hline
\end{tabular}

Sumber: Data primer diolah (2017)

Minat siswa untuk membuat sabun dievaluasi dalam bentuk post-test, yakni berupa pertanyaan essay. Hasil post-test menunjukkan bahwa terdapat empat belas faktor yang mendorong siswa mau membuat sabun (Tabel 4). Tiga faktor utama adalah siswa ingin mengetahui cara membuat sabun secara lebih dalam $(70,8 \%)$; peluang usaha $(62,5 \%)$, dan ingin membuat sabun sesuai yang diinginkan/ kreasi sabun $(29,1 \%)$

Pelaksanaan kegiatan berjalan lancar karena pihak sekolah MAN Purbalingga memberi dukungan penuh. Pihak sekolah mengizinkan penggunaan laboratorium IPA untuk pelatihan sabun suvenir serta meluangkan waktu belajar agar siswa dapat mengikuti pendidikan, pelatihan, dan praktik mandiri.

\section{SIMPULAN}

Berdasarkan hasil evaluasi kegiatan diketahui bahwa pengetahuan siswa tentang reaksi penyabunan, prinsip pembuatan sabun, bahan baku, bahan tambahan, serta peralatan untuk membuat sabun meningkat. Kegiatan ini juga mampu meningkatkan keterampilan siswa dalam memproduksi sabun suvenir dengan variasi bentuk dan warna.

Pembinaan berkelanjutan perlu dilakukan pada tahap selanjutnya untuk mendorong pelaksanaan praktik mandiri oleh siswa-siswa serta penguatan keterampilan guru pembimbing agar sabun suvenir dapat menjadi peluang wirausaha di MAN Purbalingga. 


\section{DAFTAR PUSTAKA}

Agustini, W. \& Winarni, A. H. (2017). Karakteristik dan Aktivitas Antioksidan pada Sabun Padat Transparan yang Diperkaya Dengan Ekstrak Kasar Karotenoid Chlorella pyrenoidosa. Jurnal Pascapanen dan Bioteknologi Kelautan dan Perikanan, 12(1), 112. Retrieved from https://doi.org/http://dx.doi.org/10.15578/jpbkp.v12i1.379

Cenadi, C. S. (2000). Peranan Desain Kemasan dalam Dunia Pemasaran. Retrieved from Nirmana, 2(1), 92-103.https://doi.org/10.9744/nirmana.2.2

Departemen Kesehatan R.I. (1996). Mutu dan Cara Uji Sabun Mandi. Direktorat Jenderal Pengawasan Obat dan Makanan, Jakarta.

Dunn, K. M. (2007). Soap Maker. The Journal of The Handcrafted Soapmakers Guild, (2008-2), 1-5.

Dunn, K. M. (2010). Scientific Soapmaking: The Chemistry of The Cold Process. Clavicula Press.

Hambali, E., Bunasor, T. K., Suryani, A., \& Kusumah, G. A. (2005). Aplikasi Dietanolamida dari Asam Laurat Minyak Inti Sawit pada Pembuatan Sabun Transparan. Journal of Agroindustrial Technology, 15(2), 46-53.

Hartini, S., Soetjipto, H., Ryanto, C. A., Cahyanti, M. N., \& Hastuti, D. K. A. K. (2017). Pemberdayaan Anggota PKK di Desa Lembu dalam Membuat Kosmetik. Agrokreatif Jurnal Ilmiah Pengabdian Kepada Masyarakat, 2(2), 81-86. Retrieved from https://doi.org/10.29244/agrokreatif.2.2.81-86

Herlina, Asnani, A., \& Diastuti, H. (2017). The Application of Red Pigments from Streptomyces K-4B and Dayak Onions (Eleutherine palmifolia (L.) Merr.) in Colouring Glycerine Soap. In IOP Conference Series: Materials Science and Engineering (Vol. 172). Retrieved from https://doi.org/10.1088/1757-899X/172/1/012023

Hernani, H., Bunasor, T. K., \& Fitriati, F. (2010). Formula Sabun Transparan Antijamur dengan Bahan Aktif Ekstrak Lengkuas (Alpinia galanga L.Swartz.). Buletin Penelitian Tanaman Rempah Dan Obat, 21(2), 192-205. Retrieved from https://doi.org/dx.doi.org/10.21082/bullittro.v21n2.2010.\%25p

Indonesia-SNI, S. N. (1994). Nomor 06-3532-1994 tentang Sabun Mandi Padat. Badan Standarisasi Nasional. Jakarta, 1-8.

Mabrouk, S. T. (2005). Making Usable, Quality Opaque or Transparent Soap. Journal of Chemical Education, 82(10), 1534. Retrieved from https://doi.org/10.1021/ed08 $2 \mathrm{p} 1534$

Permono, A. (2015). Membuat Sabun dan Shampo. Penebar Swadaya Grup.

Prabowo, S. A., Ardhi, M. W., \& Sasono, M. (2016). Pemberdayaan Masyarakat Desa Mojoporno Melalui Pelatihan Pembuatan Sabun dari Minyak Jelantah. Jurnal Terapan Abdimas, 1(1), 26-28. Retrieved from https://doi.org/10.25273/jta.vli1.337 
Priani, S. E., \& Lukmayani, Y. (2010). Pembuatan Sabun Transparan Berbahan Dasar Minyak Jelantah Serta Hasil Uji Iritasinya pada Kelinci. Prosiding SNaPP: Sains, Teknologi, 1(1), 31-48.

Sari, T. I., Herdiana, E., \& Amelia, T. (2010). Pembuatan VCO dengan Metode Enzimatis dan Konversinya Menjadi Sabun Padat Transparan. Jurnal Teknik Kimia, 17(3), 50-58.

Setyawan, A. (2013). Kekuatan Branding Kemasan Produk dalam Meraih Pasar. Dinamika Teknik, 7(2), 60-64.

Widyasanti, A., Farddani, C. L., \& Rohdiana, D. (2016). Pembuatan Sabun Padat Transparan Menggunakan Minyak Kelapa Sawit (Palm Oil) dengan Penambahan Bahan Aktif Ekstrak Teh Putih (Camellia Sinensis). Jurnal Teknik Pertanian Lampung (Journal of Agricultural Engineering), 5(3), 125-136.

Yuliarti, Y. (2018). Pengaruh Suhu dan Lama Pemeraman Sabun Lemak Biji Kakao (Theobroma cacao L.) Apkir Terhadap Karakteristik Mutu Sabun. Tugas Akhir D3 Agroindustri, Universitas Gadjah Mada. 